\title{
CLINICAL AND MICROBIOLOGICAL ASSESSMENT OF ROOT CANAL DECONTAMINATION IN CHRONIC APICAL PERIODONTITIS USING THE ULTRASOUND
}

DOI: 10.36740/WLek202006107

\author{
Irina M. Horlenko, Nataliia G. Gadzhula, Olena L. Cherepakha, Larysa F. Kurdysh, Olha Yu. Pylypiuk \\ NATIONAL PIROGOV MEMORIAL MEDICAL UNIVERSITY, VINNYTSIA, UKRAINE
}

\begin{abstract}
The aim: To study the effectiveness of chronic apical periodontitis treatment by the combined use of ultrasonic treatment of root canals and multicomponent antimicrobial gel according to the results of clinical and microbiological researches.

Materials and methods: 64 patients with chronic apical periodontitis at the age of 18-56 years were treated. Patients were divided into two groups: the main and control. In the main group the root canals of 36 teeth were sonicated in combination with multicomponent antimicrobial gel, in the control -35 teeth were treated by a standard method. The content of the root canals for microbiological studies was obtained before endodontic treatment and before permanent obturation. Frequency of content and number of bacteria in the samples were evaluated.

Results: All samples before treatment were positive for the presence of variable bacterial flora, among which Staphylococcus epidermidis (43.9\%), Enterococcus faecalis (37.9\%), Streptococcus spp. (24.8\%), Candida albicans (24.4\%), Fusibacterium (9.4\%) were the most dominant, their number was 7.4-4.8 $\mathrm{lg}$ CFU/ml. Repeated research after the proposed and standard method of root canal decontamination has shown a significant decrease in microflora. According to the data of clinical and microbiological examination, the method which was developed by us revealed a positive result in $86 \%$ of cases compared with $63 \%$ when treated by the standard method.

Conclusions: The effectiveness of a complex treatment method with combined use of the ultrasonic irrigation and multicomponent antimicrobial gel for root canals decontamination in chronic apical periodontitis is demonstrated. Significant reduction of microflora growth and destruction of microbial associations, good penetration of multicomponent antimicrobial gel into endodontic structures due to ultrasound compared with a standard method were achieved.
\end{abstract}

KEY WORDS: chronic apical periodontitis, endodontic treatment, root canal, ultrasound, microbiological examination

Wiad Lek. 2020;73(6):1119-1123

\section{INTRODUCTION}

Despite the continuous improvement in the quality of dental care, the prevalence of caries complications is 35$47 \%$. Chronic periodontitis remains a significant problem due to the fact that it causes tooth extraction in $48-80 \%$ of cases [1]. According to foreign researchers, in 4-10 years after endodontic treatment, up to $10 \%$ of teeth with chronic apical periodontitis are subjected to extraction [2].

The main reason for this is the presence of bacteria that remain in the root canal system. A feature of the microbiocenosis of infected root canals is the complex nature of microbial associations with a prevalence of anaerobic flora [3], among which Enterococcus faecalis stands out - an anaerobe that is resistant to many antiseptics. Microorganisms that persist in the dentinal tubules, the apical delta of the lateral canals and their branches as a result of pulp destruction and lack of blood supply maintain a state of chronic inflammation [4]. The chronic foci of infection changes the reactivity of the body and increases the resistance of microorganisms to antibacterial agents, so the fight against foci of chronic infection in the periodontal ligament is of paramount importance [5].

To eliminate microorganisms from the infected root canals system, it requires a widespread introduction of a modern strategy for endodontic antimicrobial therapy, including thorough antiseptic treatment using medicines of selective action [6-9]. An important component of the success of endodontic treatment of the teeth is the complete and qualitative preparation and obturation of the root canal $[2,10]$.

The task of the dentist at this stage of treatment is to remove the biofilm and smeared layer from the root canal system [9]. In recent years, ultrasonic systems for biomechanical treatment of root canals have emerged. The action of ultrasound based on the effects of cavitation, acoustic flow, bactericidal effects and increased bacterial activity of antiseptics $[11,12]$. The combination of modern technologies for instrumental treatment of root canals with a new generation of antiseptics is a promising direction.

\section{THE AIM}

The aim of this research was to study the effectiveness of chronic apical periodontitis treatment by the combined use of ultrasonic treatment of root canals and multicomponent antimicrobial gel according to the results of clinical and microbiological researches. 


\section{MATERIALS AND METHODS}

Clinical and laboratory studies were carried out in two groups of patients of both sexes aged 18-56 years: the main and control. In 34 patients of the main group 36 teeth were treated: 23 (63.89\%) multi-rooted and $13(36.11 \%)$ single-rooted. There were 7 (19.44\%) teeth with chronic fibrous apical periodontitis, $18(50.0 \%)$ teeth with chronic granulation and $11(30.56 \%)$ teeth with chronic granulomatous apical periodontitis. In 30 patients of the control group 35 teeth were treated: $9(25.71 \%)$ teeth with chronic fibrous apical periodontitis, 15 (42.86\%) with chronic granulation and $11(31.43 \%)$ teeth with chronic granulomatous apical periodontitis.

Treatment of various forms of chronic apical periodontitis in both groups of patients was performed for 2 visits. During the first visit the root canal preparation was carried out using the "Crown-down" technique with the help of $\mathrm{X}$-Smart endomotor and ProTaper system, irrigation of the root canals - with a $3 \%$ sodium hypochlorite solution and $15 \%$ EDTA. In the main group of patients the root canals were sonicated in combination with multicomponent antimicrobial gel using Suprasson SP 4055 ("Satelec Sas Acteon Division", France). After that in the main group of patients multicomponent antimicrobial gel (the active components of which are metronidazole benzoate, chlorhexidine diacetate $2 \%$, hydrocortisone acetate) was entered into the root canals, in the control - a $2 \%$ chlorhexidine gel was applied in the canals. The tooth cavity was isolated with a sterile cotton ball, carious cavity was filled with a temporary cement for 2 days.

On the second re-call in the main group of patients ultrasound biomechanical treatment of root canals with multicomponent antimicrobial gel was repeated, in the control - standart instrumental treatment and irrigation were carried out. In the case of positive dynamics of treatment and checking the tooth on a hermeticity, the root canals of both groups were obturated by method of lateral compaction of gutta-percha with Acroseal sealer ("Septodont", France).

The content of the root canals served as a material for microbiological research, which was obtained on the first visit before endodontic treatment and before permanent obturation. Sampling of material from a root canal was carried out before the drug administration using a sterile endodontic paper pin No. 25, which was kept in a semi-liquid transport medium at $2-4{ }^{\circ} \mathrm{C}$. Material plating was performed on the media for cultivation and identification of the microorganisms. Obtained results were expressed through the decimal logarithm $(\mathrm{lg})$ of the number of colonies of the forming units (CFU), the frequency - in per cents. To justify the choice of an antiseptic in apical periodontitis treatment, the sensitivity assessment of obtained virulent bacteria strains to multicomponent antimicrobial gel and chlorhexidine gel was determined. They were applied by the disc and hole method for gel dosage forms. The effectiveness of the proposed method of treatment was studied according to clinical, radiographic and microbiological studies in terms: during treatment, after 3, 6, 12 and 18 months. The analysis of statistical data was performed using the method of the Student parametric criterion according to the principle of variation statistics. Values of $\mathrm{p}<0.05$ were considered statistically significant.

All research methods have been examined and approved by the appropriate ethics committee and have therefore been performed in accordance with the ethical standards laid down in the Declaration of Helsinki (1964-2013), ICH GCP (1996), EEC Directive No 609 (of 24.11.1986), Orders of the Ministry of Health of Ukraine № 690 of 23.09.2009, № 944 of 14.12.2009, № 616 of 03.08.2012. An informed consent to participate in the study was received and all patients underwent standard clinical examination in accordance with the medical protocol (Order No. 566 of 11.23.2004).

\section{RESULTS}

Based on the results of microbiological researches in each patient an association of various types of bacteria was revealed, when studying the cultural spectrum of the root canal content after creation of endodontic access. From the material that was investigated, aggressive species of pathogenic bacteria and yeast-like fungi were revealed: Staphylococcus epidermidis, Streptococcus spp., Enterococcus faecalis, Peptostreptococcus spp., Fusibacterium nucleatum, Bacteroides, Prevotella spp, Candida albicans, Actinomyces spp., Lactobacillus spp. (Tables I-II).

As can be seen from the above tables, Staphylococcus epidermidis (43.9\%), Enterococcus faecalis (37.9\%), Streptococcus spp. (24.8\%), Candida albicans (24.4\%), Fusobacterium nucleatum (9.4\%) were most commonly identified in the patients of the main and control groups before treatment.

In a quantitative study of the root canal microflora in the patients of both groups, a high concentration of Staphylococcus epidermidis (7.3 $\pm 1.1 \mathrm{Ig} \mathrm{CFU} / \mathrm{ml})$, Enterococcus faecalis (5.5 $\pm 0.7 \mathrm{CFU} / \mathrm{ml})$, Streptococcus spp. (5.7 \pm 0.8 $\mathrm{Ig} \mathrm{CFU/ml),} \mathrm{Candida} \mathrm{albicans} \mathrm{(5.3} \pm 0.9 \mathrm{Ig} \mathrm{CFU} / \mathrm{ml})$ were observed before irrigation and instrumental treatment. The amount of Peptostreptococcus spp., Fusibacterium nucleatum, Bacteroides, Prevotella spp, Actinomyces spp., Lactobacillus spp. averaged $4.2 \pm 0.7 \mathrm{Ig} \mathrm{CFU} / \mathrm{ml}$.

In the main group of patients after using multicomponent antimicrobial gel in combination with ultrasound, no microbial associations of Enterococcus faecalis, Peptostreptococcus spp., Prevotella spp., Actinomyces spp., Lactobacillus spp. were revealed.

The frequency of finding other microorganisms was significantly $(\mathrm{p}<0.001)$ decreased compared with the initial results. In rare cases, Staphylococcus epidermidis $(1.6 \pm$ $0.5 \mathrm{Ig} \mathrm{CFU} / \mathrm{ml})$, Streptococcus spp. $(1.1 \pm 0.5 \mathrm{Ig} \mathrm{CFU} / \mathrm{ml})$, Candida albicans (1.2 $\pm 0.4 \mathrm{Ig} \mathrm{CFU} / \mathrm{ml})$, Bacteroides $(1.2$ $\pm 0.4 \mathrm{Ig} \mathrm{CFU} / \mathrm{ml})$, Fusobacterium nucleatum $(1.1 \pm 0.3 \mathrm{Ig}$ $\mathrm{CFU} / \mathrm{ml}$ ) were identified.

In the control group, the detection frequency and the number of bacteria after endodontic treatment also decreased compared with the initial data, however, it was remained significantly $(\mathrm{p}<0.05)$ higher than in the main group of patients. The most resistant microorganisms to standard endodontic treatment of the root canal system 
Table I. Qualitative and quantitative content of root canal microbiocenosis in chronic apical periodontitis in the main group of patients ( $\mathrm{n}=36$ )

\begin{tabular}{ccccc}
\hline \multirow{2}{*}{ Kind of microorganism } & \multicolumn{2}{c}{ Frequency of content, $\%$} & \multicolumn{3}{c}{ Bacteria concentration Ig CFU/mI } \\
\cline { 2 - 5 } & Before treatment & Before obturation & Before treatment & Before obturation \\
\hline Staphylococcus epidermidis & 42.3 & 18.1 & $7.2 \pm 1.1$ & $1.6 \pm 0.5^{*}$ \\
\hline Streptococcus spp. & 24.5 & 11.6 & $5.6 \pm 0.8$ & $1.1 \pm 0.5^{*}$ \\
\hline Enterococcus faecalis & 38.4 & 0 & $5.5 \pm 0.7$ & 0 \\
\hline Peptostreptococcus spp. & 5.9 & 0 & $4.1 \pm 0.6$ & $1.1 \pm 0.3^{*}$ \\
\hline Fusibacterium nucleatum & 9.1 & 2.3 & $4.3 \pm 0.8$ & $1.2 \pm 0.4^{*}$ \\
\hline Bacteroides & 6.0 & 1.4 & $4.3 \pm 0.7$ & 0 \\
\hline Prevotella spp & 5.5 & 0 & $4.3 \pm 0.9$ & $1.2 \pm 0.4^{*}$ \\
\hline Candida albicans & 23.5 & 5.6 & $5.2 \pm 0.9$ & 0 \\
\hline Actinomyces spp. & 4.1 & 0 & $3.9 \pm 0.7$ & 0 \\
\hline Lactobacillus spp. & 7.8 & 0 & $4.3 \pm 0.8$ & \\
\hline
\end{tabular}

Note: ${ }^{*}$ - statistically significant differences in data comparison before and after treatment, $\mathrm{p}<0.05$

Table II. Qualitative and quantitative composition of root canal microbiocenosis in chronic apical periodontitis in the control group of patients ( $\mathrm{n}=35$ )

\begin{tabular}{ccccc}
\hline \multirow{2}{*}{ Kind of microorganism } & \multicolumn{2}{c}{ Frequency of content, $\%$} & \multicolumn{2}{c}{ Bacteria concentration Ig CFU/mI } \\
\cline { 2 - 5 } & Before treatment & Before obturation & Before treatment & Before obturation \\
\hline Staphylococcus epidermidis & 41.8 & 28.9 & $7.4 \pm 1.0$ & $5.1 \pm 0.7$ \\
\hline Streptococcus spp. & 25.1 & 18.4 & $5.7 \pm 0.7$ & $4.3 \pm 0.6^{*}$ \\
\hline Enterococcus faecalis & 37.3 & 18.6 & $5.4 \pm 0.8$ & $3.7 \pm 0.6$ \\
\hline Peptostreptococcus spp. & 6.0 & 0 & $4.2 \pm 0.7$ & 0 \\
\hline Fusibacterium nucleatum & 9.7 & 6.4 & $4.8 \pm 0.8$ & $3.2 \pm 0.5$ \\
\hline Bacteroides & 5.6 & 1.7 & $4.1 \pm 0.7$ & $2.4 \pm 0.5$ \\
\hline Prevotella spp & 5.2 & 3.7 & $3.9 \pm 0.8$ & \\
\hline Candida albicans & 25.3 & 16.1 & $5.4 \pm 0.9$ & $2.3 \pm 0.4^{*}$ \\
\hline Actinomyces spp. & 4.3 & 0 & $4.1 \pm 0.8$ & 0 \\
\hline Lactobacillus spp. & 7.6 & 2.4 & $4.2 \pm 0.7$ & $2.1 \pm 0.5^{*}$ \\
\hline
\end{tabular}

Note: ${ }^{*}$ - statistically significant differences in data comparison before and after treatment, $p<0,05$

were Staphylococcus epidermidis (33.9\%; $5.1 \pm 0.6 \mathrm{Ig}$ CFU/ $\mathrm{ml}$ ), Enterococcus faecalis (18.6\%; $3.7 \pm 0.6 \mathrm{Ig} \mathrm{CFU} / \mathrm{ml}$ ), Streptococcus spp. (18.4\%; $4.3 \pm 0.6 \mathrm{Ig} \mathrm{CFU} / \mathrm{ml})$, Candida albicans $(16.1 \% ; 2.3 \pm 0.4 \mathrm{Ig} \mathrm{CFU} / \mathrm{ml})$ and Fusibacterium nucleatum (6.4\%; $3.2 \pm 0.5 \mathrm{Ig} \mathrm{CFU} / \mathrm{ml})$.

During the control examinations after root canals obturation, complications were occurred in $3(8.33 \%)$ patients of the main group and in 11 (31.43\%) patients of the control group. Pain sensations when tooth biting and a slight swelling of the soft tissues quickly disappeared after 2-3 sessions of UHF therapy.

The dynamics of radiographic changes in 3 months after the treatment was practically identical in both groups of patients, although complete bone healing in the periapical area was not observed in any clinical cases. In 6 months on the control $\mathrm{X}$-ray images of treated teeth in the main group of patients the absence of foci destruction in the periapical zone was revealed in $33.33 \%$ (12/36) of cases, and reduction of focus of apical bone resorption by $1 / 2$ or more was evidenced in $41.67 \%(15 / 36)$ of cases. In a year of dynamic evaluation in the main group of patients the expansion of destruction focus in periapical bone tissues was not established. At the same time, $58.33 \%(21 / 36)$ of patients had complete bone healing, in $27.78 \%$ (10/36) of cases the focus of bone destruction was decreased by $1 / 2$ or more from the initial sizes, and in $13.89 \%$ (5/36) of patients the resorption lesion in periapical zone was decreased by less than $1 / 2$.

In the control group of patients in $34.29 \%(12 / 35)$ of cases the lesion of resorption was decreased by $1 / 2$ or more of initial sizes, in $25.71 \%$ (9/35) of cases a partial healing of periapical bone tissue was observed, in $17.14 \%(6 / 35)$ the focus of bone destruction was not changed, in 20.0\% (7/35) of patients the widening of the periapical destruction zone was revealed. The absence of positive dynamics during 12 months of assessment in the main group of patients was noted in $13.89 \%(5 / 36)$ of cases, in the control group - in $37.14 \%(13 / 35)$ of cases.

\section{DISCUSSION}

As a result of microbiological studies, it was revealed that all root canals in both groups of patients with chronic apical periodontitis were infected with associative micro- 
flora. Facultative anaerobes from the group of gram-negative and gram-positive microorganisms prevailed in the structure of the detected microflora. Most often identified microorganisms were Staphylococcus epidermidis (43.9\%), Enterococcus faecalis (37.9\%), Streptococcus spp. (24.8\%), Candida albicans (24.4\%), Fusibacterium nucleatum (9,4\%).

The proposed method of root canal treatment using ultrasound with multicomponent antimicrobial gel promotes rapid canal treatment and complete removal of pulp decay products, qualitative irrigation of additional canals. In $86.11 \%$ of platings, the root canal microflora was sensitive to multicomponent antimicrobial gel and only in $62.86 \%$ of platings to chlorhexidine gel. Performed microbiological studies have shown that multicomponent antimicrobial gel has a prononced antibacterial effect on the mixed microflora of the root canals of treated teeth. The use of sonicated antiseptic solutions is a complete method for irrigation of the root canal system, including the macrocanals and microcanals of dentin and cementum, in which pathogenic microorganisms are located.

The traditional method of root canal decontamination is not effective enough for influencing on the pathogenic microflora of the root canals, especially with destructive forms of chronic apical periodontitis. There is a danger of further penetration of Streptococcus faecalis directly from the dentinal tubules into the periodontal tissues, and an increase in the number of fusobacteria and bacteroids.

Developed scheme of complex treatment of destructive apical periodontitis using both the ultrasound and multicomponent antibacterial gel has shown microbiological efficiency in comparison with the standard method of periodontitis treatment.

\section{CONCLUSIONS}

1. The use of ultrasonic treatment in combination with multicomponent antibacterial gel for root canal decontamination in chronic apical periodontitis allowed to achieve a negative growth of microflora and destruction of microbial associations in $86 \%$ of cases, with standard endodontic treatment - in $63 \%$ of cases $(\mathrm{p}<0.05)$. It proves a high antimicrobial activity of gel and its good penetration into endodontic structures due to ultrasound.

2. A standard endodontic treatment of the root canals is insufficient for the antiseptic action on the pathogenic microflora of the root canals, which was found in destructive forms of chronic apical periodontitis.

3. Clinical and laboratory data indicate the perspectivness and effectiveness of the combined use of ultrasonic therapy of root canals with multicomponent antibacterial gel in the treatment of chronic apical periodontitis.

\section{REFERENCES}

1. Solov'eva Zh.V. Analiz mikroflory kornevogo kanala pri endodonticheskoj patologii po rezul'tatam pervichnogo obsledovaniya pacientov [Analysis of the microflora of the root canal with endodontic pathology according to the results of the primary patients' examination]. Mezhdunarodnyj zhurnal prikladnyh i fundamental'nyh issledovanij. 2014; 2:168-172. (In Russian).
2. Shebab E.I., Din Mohamed Saber, Marwa Mohammad Aly Abou Seeda, Ehab Hassanien. The effect of instrument material, taper and degree of root canal curvature on cyclic fatigue of rotary nickel-titanium instruments. ENDO (Lond Engl.). 2013; 7 (1): 59-64.

3. Siqueira J.F., Antunes H.S., Rôças I.N. et al. Microbiome in the apical root canal system of teeth with post-treatment apical periodontitis. PLoS One; 11(9): e0162887.

4. Koval 0.V. Kliniko-laboratorne obgruntuvannia metodu obrobky korenevykh kanaliv pry likuvanni khronichnoho periodontytu: avtoref. dys. ... kand. med. nauk : 14.01.22 [Clinical and laboratory substantiation of processing method of the root canals in the treatment of chronic periodontitis]. Abstract of thesis. Odessa, 2011. 19 p. (In Ukrainian).

5. Kostiuk I.R. Vplyv patolohii periodonta na zahalnyi stan orhanizmu. Suchasni metody medykamentoznoho likuvannia periodontytu postiinykh zubiv: perevahy ta nedoliky (ohliad literatury) [Influence of periodontal pathology on the general state of an organism. Modern methods of antiseptic treatment of apical periodontitis of permanent teeth: advantages and disadvantages (literature review)]. Bukovynskyi medychnyi visnyk. 2014; T.18, 3(71):199-205. (In Ukrainian).

6. Ishkov M.0., Bielikov 0.V., Burdeniuk I.P. Kharakter mikroflory korenevykh kanaliv pry khronichnykh verkhivkovykh periodontytakh ta yii porivnialna chutlyvist do dii antymikrobnykh preparativ in vitro [The nature of root canal microflora in chronic apical periodontitis and its comparative sensitivity to the action of antimicrobial medicines in vitro]. Buk. med. visnyk. 2012; T. 16, 2 (62):67-69. (In Ukrainian).

7. Kazeko L.A. Irrigacionnye rastvory, helatnye agenty i dezinfektanty v endodontii : ucheb.-metod. Posobie [Irrigation solutions, chelating agents and disinfectants in endodontics: textbook]. In: Lobko SS, Kazeko LA. Minsk: BGMU; 2013: 48 p. (In Russian).

8. Nikolishyn A.K., Sidash Yu.V. Suchasni metody medykamentoznoi obrobky korenevykh kanaliv pry khronichnykh verkhivkovykh periodontytakh [Modern methods of antiseptic treatment of the root canals in chronic apical periodontitis]. Ukr. stomat. almanakh. 2010; 3:36-39. (In Ukrainian).

9. Antunes H.S., Rôças I.N., Alves F.R. et al. Total and specific bacterial levels in the apical root canal system of teeth with post-treatment apical periodontitis. J Endod. 2015;41(7):1037-1042. doi: S00992399(15)00240-X.

10. Gadzhula N.G. Clinical effectiveness of treatment the patients with chronic apical periodontitis. International Journal of Medicine and Medical Research. 2016; 2(2):30-33.

11. Barer G.M., Ovchinnikova I.A., Zav'yalova V.A. et al. Ul'trazvuk skvoz' prizmu endodontii [Ultrasound through the prism of endodontics]. Klinicheskaya stomatologiya. 2002; 1:32-34. (In Russian).

12. Bonsor S.Dzh., Pirson G.Dzh. Sovremennye vozmozhnosti klinicheskogo primeneniya fotoaktiviruemoj dezinfekcii [Modern opportunities of clinical applications of photoactivated disinfection]. Klinicheskaya stomatologiya. 2007; 1:24-27. (In Russian).

The work is a fragment of the research project "Modern trends and latest technologies in the diagnosis and treatment of odontopathology, diseases of periodontal tissues and oral mucous membrane", state registration No. 0118 U005471.

\section{ORCID and contributorship:}

Irina M. Horlenko - 0000-0001-8174-9651 A,B

Nataliia G. Gadzhula - 0000-0003-0016-2264 D,F 
Olena L. Cherepakha - 0000-0003-3629-4429 ${ }^{E}$

Larysa F. Kurdysh - 0000-0002-8259-9963 ${ }^{\mathrm{C}}$

Olha Yu. Pylypiuk - 0000-0002-8904-1639 ${ }^{\mathrm{F}}$

\section{Conflict of interest:}

The Authors declare no conflict of interest.

\section{CORRESPONDING AUTHOR}

Nataliia G. Gadzhula

National Pirogov Memorial Medical University

56 Pyrohov Str., 21018 Vinnytsia, Ukraine

tel: +380977011918

e-mail: natalidentist1@gmail.com

Received: 20.02 .2020

Accepted: 30.04 .2020 